\title{
Analysis of the Ugandan Experience on Teacher Job Satisfaction and Students' Academic Performance at Uganda Certificate of Education in Secondary Schools in Western Uganda
}

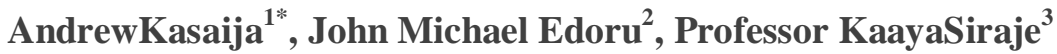 \\ ${ }^{1}$ Masters Candidate, Kabale University, Kabale University, Uganda \\ ${ }^{2} \mathrm{PhD}$, University of South Africa, Kabale University, Uganda \\ ${ }^{3}$ Professor of Business Leadership and Management, Kabale University
}

*Corresponding Author: Andrew Kasaija, Masters Candidate, Kabale University, Kabale University, Uganda

\begin{abstract}
The purpose of the study was to investigate the relationship between teachers' job satisfaction and students' academic performance at Uganda Certificate of Education in secondary. A causal comparative research design was employed for the study. Purposive and simple random sampling techniques were used to select the participants from selected secondary schools. Quantitative and qualitative data was collected for triangulation. The target population was 168 and the sample size was 120. The findings from the study indicated that the nature of working conditions were still favorable to some employees. Finally, the researcher recommended that there is need to improve on the intrinsic and extrinsic factors of job satisfaction of teachers that influence academic performance and ways of improving intrinsic and extrinsic factors of job satisfaction of teachers so as to improve academic performance at Uganda Certificate of Education level in secondary schools in Western Uganda particularly in Kamwenge district.
\end{abstract}

Keywords: Motivation, Job Satisfaction, Secondary Schools, Intrinsic Motivation, Extrinsic Motivation, Academic Performance.

\section{INTRODUCTION}

Many studies have been done on job satisfaction for over six decades now and thousands of articles have been published Zembylas \& Papanastasiou, (2006) ${ }^{1}$. However, most of the studies have been done in developed countries such as United States of America, United Kingdom, Canada and New Zealand but few carried out in the developing countries (ibid). This implies that there is more literature available on teachers' job satisfaction from the developed countries than from developing countries.

Teacher motivation has become an important issue given their responsibility to impart knowledge and skills into learners. It is argued that satisfied teachers are generally more productive and can influence students' achievement In third world countries, it seems that the issue of job satisfaction is taken lightly and that's why there have been many cases of job turnovers in schools, cases of indiscipline, absenteeism and underperformance. In Malawi, Kadzamira, Lemani, Lewin \& Stuart (2003) ${ }^{2}$ in their research studies concluded that the overall levels of job satisfaction and motivation are low in both primary and secondary schools. Teachers are highly dissatisfied with their remuneration and other conditions of service. Problems of teacher job satisfaction have also been cited in Nigeria, where teachers' agitations and demands for improved compensation are given little attention due to the problem of the inadequate resources in the Ministry of Education, to meet satisfactory needs of the

${ }^{1}$ Zembylas, M.,andPapanastasio, E.C.(2006).Sources of Teacher Job Satisfaction andDissatisfaction in Cyprus. A Journal of Comparative Education, 36(2), (online). Available:www.sciepub.com/reference/134044. Accessed on, 30, March, 2017.

${ }^{2}$ Kadzamira, Lemani, Lewin \& Stuart .(2003). Teacher Motivation in Sub-Saharan Africa and South Asia Available(Online)athttps://assets.publishing.service.gov.uk/media/57a08be640f0b652dd000f9a/ResearchingtheI ssuesNo71. [accessed on 02/24/2017] 
workers. As a result, the government of Nigeria and the Nigerian Union of Teachers (NUT) are in constant stand-offs over the increase in salaries, benefits, and improving the working conditions of teachers (Nwachukwu, 2006) ${ }^{3}$. Since independence in 1962, job satisfaction has remained an imperative point to ponder in most Ugandan organizations. Griffin (2005) stated that the performance of an individual is determined by three factors i.e. motivation, work environment and ability to do work. Teacher performance in this study was measured basing on the Uganda Certificate of Education results (2013-2016). While other profession enjoy a high degree of self-regulation and are successful in maintaining high barriers to entry in terms of qualification requirements and registration, teachers on the other hand, tend to have weak, state-dominated professional organizations with several trade unions. In addition, public sector recruitment freezes in many countries during the 1990s have seriously constrained the growth of the number of teachers in government or government-aided schools. Although such events are expected to have affected the morale of teachers to perform, detailed studies examining the effects of motivation on performance of teachers are still scanty. Available evidence, however, reveals that the teaching force has expanded rapidly in only a relatively few countries (most notably Bangladesh, Malawi, Ethiopia, Eritrea, Mozambique and Uganda). Teachers often lack a strong, long term commitment to teaching as a vocation. This has had important implications for intrinsic motivation of school teachers.

In Uganda, the Ministry of Education and Sports controls primary and other levels of education. The primary school system since independence has continued to expand, through service providers such as government and the private sector who have been encouraged to open up schools. According to the Government White Paper, (1992) recommended use of distance education and opening up learning centres, which has created the challenges of increased demand for education and expansion of education system.

Consequently, in Kamwenge district, a report by the District Education Officer (2006) revealed that teachers were devoting less and less time to extra-curricular activities, teaching preparation, and marking. Therefore, deteriorating standards of professional conduct, including serious misbehaviour (in and outside of work), and poor professional performance have been observed in some secondary schools.

Attempts to improve performance in schools will never succeed if teachers' job satisfaction is ignored. If employees in an organization are motivated, they will render services to the employer and customers very efficiently and effectively Mbua, $(2003)^{4}$. This implies that motivated and satisfied secondary school teachers are most likely to affect the students' learning positively while the opposite of that may have negative impacts on students' performance. It is against this background that the researcher initiated a study to investigate the effect of teachers' job satisfaction on academic performance at UCE in secondary schools in Kamwenge district.

\subsection{Theoretical Underpinnings of the Study}

This study was informed by Herzberg's Two Factor Theory because it contains both factors that lead to satisfaction and dissatisfaction. Hertzberg (1957) labelled factors causing dissatisfaction of workers as hygiene factors because these factors were part of the context in which the job was performed, as opposed to the job itself. Frederick Hertzberg's Two-factor theory, also known as MotivationHygiene theory or intrinsic and extrinsic motivation, concludes that there are certain factors in the workplace that can cause job satisfaction and a separate set of factors that can cause dissatisfaction. It is critical to emphasize that this is not a linear relationship: the factors that cause satisfaction do not necessarily negate those that cause dissatisfaction; one does not necessarily increase exactly as the other decreases.

Extrinsic motivators (Hygiene factors) tend to represent more tangible, basic needs-that is, the kinds of needs identified by Clayton's "Existence" category of needs in his Existence Relatedness Growth

\footnotetext{
${ }^{3}$ Nwachukwu. (2006). Benchmarking the Motivational Competencies of Academically Qualified Teachers and Professionally Qualified Teachers in Nigerian Secondary Schools.http:www.ccsenet.org/journal.html (Accessed: 9 October 2017).

${ }^{4}$ Mbua, (2003).The Study of Teachers' Job Satisfaction in Junior Secondary Schools. Abronline.org/journals/ index.php/eaje/article/view/474/493. (online),Available: (accessed on 30, March,2017).
} 
(ERG) Theory or in the lower levels of Maslow's Hierarchy of Needs. Extrinsic motivators include; status, job security, salary, and fringe benefits. Managers must realize that not providing the appropriate and expected extrinsic motivators will show dissatisfaction and unmotivated behaviour among employees.

Intrinsic motivators tend to represent less tangible, more emotional needs that is, the kinds of needs identified in Claytons' "Relatedness" and "Growth" categories of needs in his ERG Theory and in the higher levels of Maslow's Hierarchy of Needs. Intrinsic motivators include: challenging work, recognition, relationships, and growth potential. Managers must recognize that while these needs may be outside the more traditional scope of what the workplace should provide, they are absolutely critical in empowering strong individual and team performance.

\subsection{Statement of the Problem}

The results at Uganda Certificate of Education show that performance in all subjects is still poor in most schools despite the government's investments made to ensure good performance. According to Ololube, $(2013)^{5}$ teachers argue that the existing salary structure, benefits and working conditions do not satisfy their basic needs. Other sectors of the economy have bigger salary structure, better motivation and enhanced working conditions.

Since 2008, most of the students who sit for Uganda Certificate of Education in Kamwenge district pass with divisions Four and Nine. Experts are sharing the blame among parents, teachers and government. There were efforts initiated in 2007 such as improved sanitation, improved water supply, multi-purpose science rooms and libraries, as well as increased supplies of science kits. However, with all these in place, trends since 2008 show that there has been a decline in the academic performance at Uganda Certificate of Education in secondary schools in Kamwenge district. Therefore, the research problem which entails the teachers' job satisfaction and academic performance at Uganda Certificate of Education in secondary schools in Kamwenge district in Uganda has been investigated in order to establish the reasons for their persistent poor performance.

\subsection{Objectives of the Study}

- To explore the intrinsic and extrinsic factors of job satisfaction of teachers that influence academic Performance at Uganda Certificate of Education secondary schools in Kamwenge district, Uganda.

- To examine the factors Influencing Academic Performance of students' at Uganda Certificate of Education in secondary schools in Kamwenge district, Uganda

- To explore ways of improving intrinsic and extrinsic factors of job satisfaction of teachers so as to improve academic performance at in secondary schools in Kamwenge district, Uganda.

\subsection{Research Questions}

- What are the intrinsic and extrinsic factors of job satisfaction of teachers that influence academic performance at Uganda Certificate of Education secondary schools in Kamwenge district, Uganda?

- What are the factors that Influence academic performance of students' at Uganda Certificate of Education in secondary schools in Kamwenge district, Uganda?

- How can improvement in extrinsic and intrinsic factors of job satisfaction of teachers influence academic performance at Uganda Certificate of Education in secondary schools in Kamwenge district, Uganda?

\section{LITERATURE REVIEW}

\subsection{The Intrinsic Factors of Job Satisfaction of Teachers that Influence Academic Performance at Uganda Certificate of Education Secondary Schools}

\footnotetext{
${ }^{5}$ Ololube, N. P. (2010). Teachers Job Satisfaction and Motivation for School Effectiveness: An Assessment: University of Helsinki, Finland.
} 
Intrinsic rewards include: professional development, nature of work itself and sense of achievement Latham, (1998) ${ }^{6}$. The phenomenon of job satisfaction is associated with five main factors namely: achievements, recognition, work itself, responsibility and advancement, and they refer to these factors as the basic satisfiers or motivators Herzberg (1959).According to (Woods and Weasmer2002) ${ }^{7}$, workers' job satisfaction is derived from collegial relationship that they enjoy at their place of work. It is very important for teachers to have time to share experiences. Relationships of the workers with individuals in the organization, such as their supervisor, peers, and subordinates, are what interpersonal relations are comprised of and are one more gauge of satisfaction or dissatisfaction.

Shann, $(2001)^{8}$, found that teachers derived their job satisfaction from the relationship they had with their pupils and thus this factor was ranked higher than the rest of the job facts. The other factor that was also important according to her is job security.

Conversely, in her study, the aspect of pay was ranked as the least of all among the fourteen facets. In other words, the participants in the study expressed low satisfaction with this job facet. The seven major aspects/factors of job satisfaction according to Vroom are: administration, promotion, job nature, superiors, salary remuneration, working conditions and colleagues. Additionally, the teachers derive their satisfaction from such factors as: salaries, fringe benefits, educational policies and administration, working conditions, advancement opportunities, responsibilities within the job recognition, and this implies that teacher job satisfaction can also be derived from what Herzberg refers to as dissatisfaction, that is, salary, company policies, administration and working conditions among others Bolin, (2007) 9 .

\subsection{Extrinsic Factors of Job Satisfaction of Teachers Influence Academic Performance at Uganda Certificate of Education Secondary Schools}

Employers should strive to improve the quality of work life of all employees, to ensure job satisfaction and increased productivity. Quality of work life refers to the negative or positive feelings employees have about the circumstances in their workplace. Management should therefore, identify the indicators causing dissatisfaction and implement the appropriate interventions.

Everyone in the workplace has an important part to play in organizational performance, which is a result of high quality, functioning staff within an organization. Therefore, understanding employee job satisfaction is important for the transformation of performance and productivity in an institution as observed by (Nyanga, Mudhovozi, Chireshe\&Maunganidze,2012) ${ }^{10}$. This influence of job satisfaction remains a challenge for academics in Higher Education, in terms of their own and that of students' overall performance.

According to (Long \&Swortzel, 2007), job performance should periodically be measured by organizations, in an attempt to ensure the maintenance and improvement of messages and work practices, as and where necessary. The authors further indicate that the effectiveness of the individual employee in the workplace is determined by job performance. It is, nonetheless, the responsibility of the organization to inform its employees of its mission and objectives. This is supported by (Saetang, Salumnad, Thampitak\&Sungkaew, 2010) ${ }^{11}$, who indicate that the success or failure of organizations depends on job performance of the individual in that organization, and this job performance can easily be translated into job satisfaction. The organization makes use of policies that facilitate employee

\footnotetext{
${ }^{6}$ Latham, A. (1998).Teacher Satisfaction. Association of Supervision and Curriculum Development, 82-83.

${ }^{7}$ Woods, A. M. and Weasmer, (2002). Maintaining Job Satisfaction; Engaging Professionals as Active Participants. The Clearing House. 75, No. 4, 186 - 189.

${ }^{8}$ Shann, M. H.(2001). Professional Commitment and Satisfaction among Teachers in Urban Middle Schools. The Journal of Educational Research,92 No2,67-73.

${ }^{9}$ Bolin (2007).A Study of Teacher Job Satisfaction and Factors That Influence It https://www.researchgate.net/ publication/250172810_A_Study_of_Teacher_Job_Satisfactionvol.40, no. 5

${ }^{10}$ Nyanga, T. Mudhovozi, P. Chireshe, R. and Maunganidze, L. (2012).A survey of Satisfaction Of Employees at Higher Learning Institutes in Masvingo Province. ZimbabweanAnthropologist. 14(1): 73-79.

${ }^{11}$ Saetang, J., Sulumnad, K.,Thampitak, P., and Sungkaew, T. (2010). Factors Affecting Perceived Job Performance among Staff: A case study of Ban KarunaJuvenil Vocational Training Center for Boys. The journal of Behavioral sciences, 5(1): 33-45.
} 
satisfaction, to create an atmosphere of commitment and cooperation for its staff, thus ensuring that firm goals are achieved as stressed by (Parvin and Kabir, 2011) ${ }^{12}$.

\subsection{Factors Influencing Academic Performance at Uganda Certificate of Education Secondary School}

In identifying employees' strengths and areas requiring improvement, developmental and promotional opportunities can be planned, as well as the necessity of academic advancement, for example, be encouraged to undertake research, be accorded opportunities for training and development, as well as promotions and strengthening the overall working relationship between managers and employees. This boosts academic morale and motivates them to work harder, since they realize that they are deemed part of the organization and therefore become motivated through recognition as stressed by Maya, $(2007)^{13}$.

\subsection{Ways of Improving Intrinsic and Extrinsic Factors of Job Satisfaction of Teachers so as to Improve Academic Performance at in Secondary Schools}

Since the goal of current school reform efforts is to improve student achievement, these efforts are well-aligned with the primary motivator of teachers - the power to help children learn. (Zemmelman, Daniels \& Hyde, 1993), ${ }^{14}$ wrote that teachers' attitudes are crucial to the success of in-depth curricular innovation. Moreover, the beneficial effort of teachers' attitudes on education reform is reciprocal. Some research shows that when principals effectively use shared governance strategies and participatory management, teachers feel energized and motivated, and their sense of ownership and empowerment increases as observed by (Blasé \&Blase, 1994). ${ }^{15}$ Well-implemented school improvement plans can increase collegiality and give teachers the satisfaction to committing themselves to school improvement goals. Some practitioners believe that such rewards may be more effective in motivating teachers and improving teaching practices than individual, extrinsic rewards as stressed by Johnson, (1986). ${ }^{16}$

The interrelation of teacher motivation and school reform efforts has also been addressed through the issue of staff development. Traditionally, staff development has meant encouraging teachers to enhance pedagogical skills and knowledge of subject matter through advanced academic study at the graduate level; providing funding for conferences and workshops; and developing other training opportunities, including in service programmes. Lieberman, (1995), ${ }^{17}$ argues for a radical rethinking of professional development that encourages teachers' growth. She believes that teachers must have opportunities to try out new practices by taking new roles and creating a culture of inquiry. Monahan, (1996), ${ }^{18}$ describes a new concept known as Comprehensive Professional Development (CPD), which focuses on strategies for facilitating teacher growth through professional dialogue with colleagues, collaborative curriculum development, peer supervision, peer coaching, and action research leading to school wide change. Problem-Based School Development (PBSD) is an approach that takes staff development and school form to the next level by creating a professional community capable of sustaining long term educational reform.

According to Frase, (1992), ${ }^{19}$ recognition and feedback have been cited as important motivators for teachers, so it would seem that evaluation is an obvious vehicle for driving these incentives to direct

\footnotetext{
${ }^{12}$ Parvin, M. M., and Kabir, M. M. N.(2011). Factors Affecting Employee Job Satisfaction of Pharmaceutical Sector: Australian journal of business management research.1 (9): 113- 123.

${ }^{13}$ Maya, M.(2007). International Human Resources and Labour Relations Management Academy of New York.

${ }^{14}$ Zemmelman,S. Harvey .D, and Arthur, (1993). Best Practice: New Standards for Teaching and Learning in America's Schools. Portsmouth, NH: Heineman.

${ }^{15}$ Blasé.J. and Blasé.J.R, (1994). Empowering Teachers: What Successful Principals Do. Thousand Oaks, CA: Corwin Press, Inc.

${ }^{16}$ Johnson and Susan M, (1986). Incentives for Teachers: What Motivates, What Matters. Educational Administration Quarterly Vol. 22, No. 3

${ }^{17}$ Lieberman.A. (1995). Practices that Support Teacher Development.Phi Delta Kappan Vol.76 No.8: 591-596.

${ }^{18}$ Monahan .T. C, (1996). 'Do Contemporary Incentives and Rewards Perpetuate Out-dated Forms of Professional Development'? Journal of Staff Development Vol. 17. No1 (Winter

${ }^{19}$ Frase.E. and Larry.S, (1992).Teacher Motivation and Satisfaction: Impact onParticipatory Management. NASSP Bulletin (January 1992): 37-43.
} 
the teachers on the path towards professional growth and improvement. Peterson $(1995)^{20}$ calls for a new direction in teacher evaluation that will bring better results more allied to the goals of comprehensive professional development and the goals of education reform.

However despite the studies conducted, more research studies need to be conducted in areas of the factors which affect teachers' job satisfaction and academic performance and ways through which intrinsic and extrinsic factors can be improved so as to improve academic performance in secondary schools in Uganda, Kamwenge district and this is the one that has prompted the researcher to undertake this study so as to fill the gaps left by other researchers.

\section{RESEARCH METHODOLOGY}

The researcher discussed the description of the research design (a master plan for data collection and analysis), research population, sample size and sampling procedures and instruments of data collection, the validity and reliability of measuring procedures, data analysis techniques, ethical considerations, data management, interpretation and anticipated.

\section{DISCUSSION}

The respondents were asked of their profiles and the findings revealed that, on respondents' gender, the results obtained show that the majority of workers in were males $66.7 \%$ and females were $33.3 \%$. On respondents' age, the study revealed that the $43.3 \%$ of the respondents were between the ages of ages of 31- 45 years, meaning that majority of the respondents in their youth full ages were considered most effective at work.

The study also discovered the respondent's educational level and the study revealed that $8.3 \%$ had "A" level, 61.6 had Diploma, 27.5\% had a Bachelor's degree and 2.5\% had a Master's degree.

The findings in the study discovered that there is relationship with colleagues, recognition, advancement and supportive administration. According to Latham (1998) ${ }^{21}$ intrinsic rewards include such issues as: professional development, nature of work itself and sense of achievement. The phenomenon of job satisfaction is associated with five main factors namely: achievements, recognition, work itself, responsibility and advancement, Herzberg, Mausner\&Snyderman (1959) ${ }^{22}$ and they refer to these factors as the basic satisfiers or motivators Herzberg (1959). ${ }^{23}$

With regards to relationship with colleagues, findings revealed that teachers were happy to work hard because of the satisfaction they obtained from the friendships they had established with co-workers, students, and parents. These results support the findings of previous studies, such as that by (Woods and Weasmer2002) ${ }^{24}$ workers job satisfaction is derived from collegial relationship that they enjoy at their place of work. It is very important for teachers to have time to share experiences.

With regard to recognition findings revealed that teachers expressed satisfaction with teaching when they perceived that community members recognize and respect their contribution to education. This is in line with (Dinham\& Scott, 2000), ${ }^{25}$ who proposed that status and seniority and general life satisfaction are some of the factors that satisfy employees.

The findings revealed that timely and regular promotions would contribute to their comfort with the profession, but they reported that often their deserved or expected promotions were not realized. The teachers stated that lack of timely promotion hindered their readiness to serve their employer.

It was revealed from study findings that teachers are extrinsically satisfied with salary, incentives, fringe benefits, organization policies, autonomy, working conditions, job security, leadership and supervision.

\footnotetext{
${ }^{20}$ Peterson and Kenneth D, (1995). Teacher Evaluation: A Comprehensive Guide to New Directions and Practices. Thousand Oaks, CA: Corwin Press, Inc.

${ }^{21}$ Latham, A. (1998).Teacher Satisfaction. Association of Supervision and Curriculum Development, 82-83.

${ }^{22}$ Mausner, B. \&Snyderman, B., (1959).Motivation to Work. New York: John Wiley\& Sons

${ }^{23}$ Herzberg, F. (1959).The Motivation to Work. New York. Wiley.

${ }^{24}$ Woods, A. M. and Weasmer, (2002). Maintaining Job Satisfaction; Engaging Professionals as Active Participants. The Clearing House. 75, No. 4, 186 - 189.

${ }^{25}$ Dinham,S. and Scott, C. (2000).Moving into the Third Outer Domain of Teacher Satisfaction.Journal Educational Administration, 38, No. 4, 379- 396.
} 
With regard to salary, most respondents desired their income to correspond to their workload. Thus, such aspects as monthly salaries, transfer allowances, periodic adjustments to their salary scales, and leave allowances had to be realistic. This is in line with (Santhapparaj\&Alam, 2005), ${ }^{26}$ who indicated that pay is among those factors that have a positive and significant effect on job satisfaction.

Attractive remuneration packages enhanced teachers' attachment to schools. Yet government secondary school teachers had fixed salary scales determined centrally by the government. (Hashim\&Mahmood, 2011), ${ }^{27}$ indicated that policy makers and academic leaders at secondary schools should earnestly consider having their compensation system and practices benchmarked against other educational institutions or service industries' best practices.

Findings showed that teachers' positive feelings about workplace conditions enhanced their work in a way that promoted their attachment to the job. As argued by Odhiambo(2005) ${ }^{28}$ productivity at the workplace is optimized when workers perceive sufficient attention being given to their physical work facilities. Teachers asserted that their teaching life was difficult when workplace conditions lacked basic teaching facilities and resources.

The researchers discovered from the study that school reforms, professional development, induction and support of new teachers and teacher evaluation as ways of improvement on intrinsic and extrinsic factors of job satisfaction of teachers. This influences academic performance at Uganda Certificate of Education secondary schools in Kamwenge district in Uganda. This is in line with Monahan (1996) ${ }^{29}$ who describes a new concept known as Comprehensive Professional Development (CPD), which focuses on strategies for facilitating teacher growth through professional dialogue with colleagues, collaborative curriculum development, peer supervision, peer coaching, and action research leading to school wide change.

From the findings, respondents displayed happiness with the profession when they were provided with an opportunity for academic and professional development, as well as timely promotion. This enhanced their advancement in the realm of skills, capacity, and experience. Teachers' loss of morale, especially in government secondary schools, had roots in their loss of hope that the government would address their concerns regarding salary scales and timely promotion. Such results align with findings on a study regarding predictors of job satisfaction among Nigerian teachers by Ololube (2010). ${ }^{30}$ Results revealed that employees who perceive limited opportunities for career advancement and low salary have decreased job satisfaction.

\section{CONCLUSION AND RECOMMENDATIONS}

The researchers concluded that teachers were intrinsically satisfied with the relationship with colleagues, recognition, advancement and supportive administration. Also, teachers were extrinsically satisfied with salary, incentives, fringe benefits, organization policies, autonomy, working conditions, job security, leadership and supervision.

The researchers concluded that quality of Work Life, Maintenance and Improvement of messages and work practices, performance policies, developmental and promotional opportunities influence teachers' morals, which in turn affect students' performance.

The researchers concluded that there is need for secondary schools to improve intrinsic and extrinsic factors to improve teachers' job satisfaction. From the discussion, use of forward strategies to improve teachers' job satisfaction should be put in place. Such ways include: school reforms,

\footnotetext{
${ }^{26}$ Santhapparaj, A. S. and Alam, S. S,(2005). Job Satisfaction Among academic Staff in Private Universities in Malaysia. Journal of social sciences, 1(2): 72-76.

${ }^{27}$ Hashim, R. A. and Mahmood, R. (2011). What is the State of Job Satisfaction Among AcademicStaff at Malaysian Universities: Universititun Abdul Razakae-journal 7(1).

${ }^{28}$ Odhiambo. G. O. (2005). Teacher Appraisal: The Experiences of Kenyan Secondary School Teachers. Journal of Educational Administration. 43 (4), 402-416

${ }^{29}$ Noordin, F.(2009). Levels of Job Satisfaction Amongst Malaysian Academic Staff. Asian SocialScience (online), 5(5):122-128. Available: (Accessed: 9 October 2011).

${ }^{30}$ Ololube, N. P. (2010). Teachers Job Satisfaction and Motivation for School Effectiveness: An Assessment: University of Helsinki, Finland.
} 
professional development, induction and support of new teachers and teacher evaluation. All these should be done if teachers' job satisfaction is to be realized.

Intrinsic factors of job satisfaction for teachers such as: Comprehensive Professional Development and recognition should be improved upon so as to improve academic performance at Uganda Certificate of Education secondary schools in Kamwenge district in Uganda.

Extrinsic factors of job satisfaction of teachers such as: salary, job security, allowances and conditions of work should be improved upon so as to improve academic performance at Uganda Certificate of Education in secondary schools in Kamwenge district in Uganda.

Government should allocate more funds to increase on teachers' salaries and allowances. Through inspection reports and teacher appraisal, best performing teachers should be recognised, sponsored for further studies and promoted to better positions so as to improve academic performance at Uganda Certificate of Education in secondary schools in Kamwenge district in Uganda.

\section{REFERENCES}

[1] Blasé.J. and Blasé. (1994). Empowering Teachers: What Successful Principals Do.Thousand Oaks, CA: Corwin Press, Inc.

[2] Bolin. (2007).A Study of Teacher Job Satisfaction and Factors That Influence It https://www.researchgate. net/publication/250172810_A_Study_of_Teacher_Job_Satisfactionvol.40, no. 5

[3] Buchanan. K. (2010). Job Performance and Satisfaction (online), Available: http://ezinearticles.com. (Accessed on 12 January, 2017).

[4] Dinham.S. and Scott. (2000). Moving into the Third Outer Domain of Teacher Satisfaction. Journal Educational administration, 38, No. 4, 379- 396.

[5] Evans. N. (1997). Head Classes and Agreement Classes in the Mayali Dialect Chain. In Harvey, Mark and Reid, Nicholas (eds.), Nominal Classification in (online), Available: wals.info/refdb/record/Evans-1997. (Accessed on 12 January, 2017).

[6] Frase. E. and Larry. (1992). Teacher Motivation and Satisfaction: Impact on Participatory Management. NASSP Bulletin (January 1992): 37-43.

[7] Government of Uganda (1992).Government White Paper on Implementation of the Recommendations of the Kajubi Report1989. (Online).Available:https://searchworks.stanford.edu/view/3479618 (Accessed 6,Janaury, 2017).

[8] Hashim, R. A. and Mahmood. R. (2011). What is the State of Job Satisfaction Among Academic Staff at Malaysian Universities: Universititun Abdul Razakae-journal 7(1).

[9] Herzberg. F. (1959).The Motivation to Work. New York. Wiley.

[10] Herzberg, F. Mausner. B. \&Snyderman, B., (1959). Motivation to Work. New York: John Wiley\& Sons

[11] Higher Education South Africa (HESA) Insight. (2009). (online), Available: www.hesa.org.za,Issue 01 October (Accessed March, 2017)

[12] Johnson and Susan .M.(1986). Incentives for Teachers: What Motivates, What Matters. Educational Administration Quarterly Vol. 22, No. 3

[13] Jonathan.H. Darroux. C and Thibeti.M. (2013) "Exploring the Effect of Job Satisfaction and Demographic Factors on Affective, Normative and Continuance Commitment: An empirical Evidence of Public Secondary School Teachers in Tanzania," Journal of Education and Practice, vol. 4, no. 23, pp. 85-96, 2013. Viewed at Google Scholar

[14] Kadzamira, Lemani, Lewin \& Stuart .(2003). Teacher Motivation in Sub-Saharan Africa and South Asia Available(Online)athttps://assets.publishing.service.gov.uk/media/57a08be640f0b652dd000f9a/Researchin gtheIssuesNo71.[accessed on 02/24/2017]

[15] Kirsten, H. W.(2011). Human Resources Management N Series. Ed: Anthony Hill.

[16] Kirsten, H. W. (2012). Human Resource Management N Series. Ed: Anthony Hill.

[17] Kyambalesa. H. (1998). The keys to success in management, England: Aslgate Publishing Company .

[18] Latham, A. (1998).Teacher Satisfaction. Association of Supervision and Curriculum Development, 82-83.

[19] Lieberman, A.(1995). Practices that Support Teacher Development. Phi Delta Kappan Vol.76 No.8: 591596.

[20] Maicibi, N. A. \&Nkata, J. L. (2005). Introduction to human resource management, (1st Ed.), Masah Publications, Kampala. 
[21] Malik, M. E. Danish, R. Q, and Munir, J, (2012). The Impact of Pay and Promotion on Job Satisfaction: Evidence from Higher Education Institutes of Pakistan: American journal of Economics. Special issue 6-9.

[22] Maya, M.(2007). International Human Resources and Labour Relations Management: Academy of New York.

[23] Mapesela and Hay, (2006).A case study of the working environment of South African ... available at http://journals.sagepub.com/doi/pdf/10.1177/1745499915571721 [accessed on 08/07/2017]

[24] Mbua, F. N. (2003). The Study of Teachers' Job Satisfaction in Junior Secondary Schools.

[25] Abronline.org/journals/index.php/eaje/article/view/474/493. (online), Available: (accessed on 30, March, 2017).

[26] Monahan, T. C. (1996). 'Do Contemporary Incentives and Rewards Perpetuate Out-dated Forms of Professional Development'? Journal of Staff Development Vol. 17. No1 (Winter 1996):44-47.

[27] Morris, M. G. and Venkatesh. V. (2010). Job Characteristics and Job Satisfaction: Understanding the Role of Enterprise Resource Planning Systems Implementation. MIS Quarterly, 34(1): 143-161 March 2010.

[28] Mullins, L. J. (2002). Management and organization behavior. (4 Ed.), Pitman publishing. England: Prentice Hall.

[29] The New Vision, Monday, September 5, 2011, pages 2, 3 Kampala.Vol.26 No.176.

[30] Noordin, F.(2009). Levels of Job Satisfaction Amongst Malaysian Academic Staff. Asian Social Science (online), 5(5):122-128. Available: (Accessed: 9 October 2011).Teachers and Professionally Qualified Teachers in Nigerian Secondary Schools.http:www.ccsenet.org/journal.html (Accessed: 9 October 2017).

[31] Nyanga, T. Mudhovozi, P. Chireshe. R. and Maunganidze. L. (2012). A survey of Satisfaction Of Employees at Higher Learning Institutes in Masvingo Province. Zimbabwean Anthropologist. 14(1): 7379.

[32] Odhiambo, G. O. (2005). Teacher Appraisal: The Experiences of Kenyan Secondary School Teachers. Journal of Educational Administration. 43 (4), 402-416

[33] Ololube, N. P. (2010). Teachers Job Satisfaction and Motivation for School Effectiveness: An Assessment: University of Helsinki, Finland.

[34] Ololube, N. P. (2013). Teachers Job Satisfaction and Motivation for School Effectiveness: An Assessment: University of Helsinki, Finland.

[35] Oluseye, O. O. Amos. A. O, and Abiola, O. O.(2014). Effect of Motivation on Job Satisfaction of Selected Sales Representatives. Journal of Educational and Social Research. 4(1): 197-203.

[36] Onen,J.C.(1998). Educational Research:Statistics and Measurement: (2 ${ }^{\text {nd }}$. ed).Makerere University, Kampala: Department of Distance Education, Institute of Adult and Continuing Education.

[37] Oshagbemi, T, (1999). Academics and their managers: A comparative Study in Job Satisfaction.1 (28): 108-123.

[38] Oso, W.Y \&Onen D, (2008). A General Guide to writing Research Proposal and Report: A Handbook for beginning researchers. ( ${ }^{\text {nd }}$ Ed.). Kampala: Makerere University.

[39] Parvin, M. M and Kabir, M. M. N.(2011). Factors Affecting Employee Job Satisfaction of

[40] Pharmaceutical Sector:Australian journal of business management research.1 (9): 113-123.

[41] Peng, S. S and Wright. D.(1994). Explanation of Academic Achievement of Asian -American Students. Journal of Educational Research, 87 (6), 346-352.

[42] Phillips, M. (998). Family Background, Parenting Practices, and the Black-White Test Score Gap; The black-white test score gab, Washington, D.C., Brooking Institution Press.

[43] Robbins, S. P. and Judge. T. A, (2003). Essentials of Organizational Behavior. New Jersey: Pearson Education.

[44] Rollins, B. C. and Thomas, D. L. (1979). Parental Support, Power, and Control Techniques in The Socialization of Children. In W. R. Burr, R. Hill, F. I. Nye, \& I. L. Reiss (Eds.), Contemporary Theories About the Family, Vol. L (pp. 317-364). New York: The Free Press, Macmillan.

[45] Saba, I, (2011). Measuring the Job Satisfaction Level of the Academic Staff in Bahawalpur Colleges. International journal of academic research in business and social sciences, (1).

[46] Saba, I. and Iqbal. F.(2013). Determining the Job Satisfaction Level of the Academic Staff at Tertiary Academic Institutes of Pakistan. International SANANM journal of business.

[47] Seating, J. Sulumnad. K. Thampitak, P. and Sungkaew. T. (2010). Factors Affecting Perceived Job Performance among Staff: A case study of Ban KarunaJuvenil Vocational Training 
[48] Center for Boys. The journal of behavioral sciences, 5(1): 33-45.

[49] Saint, W. (2009). Legal Frameworks for Higher Education Governance in Sub-Saharan Africa: Higher Education Policy.22 (1): 523-550.

[50] Santhapparaj. A. S. and Alam. S. S.(2005). Job Satisfaction Among academic Staff in Private Universities in Malaysia. Journal of social sciences, 1(2): 72-76.

[51] Schultze. C. M. (2009). Building a Human resource Strategy for a Major Higher Education Institution in South Africa; South African journal of labour relations, 33(2): 100-119.

[52] Shafritz, O.\& Jang. (2005). Classics of Organization Theory. Belmont, USA: Wadsworth.

[53] Shann, M. H.(2001). Professional Commitment and Satisfaction among Teachers in Urban Middle Schools. The Journal of Educational Research,92 No2,67-73.

[54] Spector, P. E. (1997).Measurement Invariance of the Job Satisfaction Survey Across Work. (online), Available:www4.ncsu.edu/ awmeade/Links/Papers/JSS_MI(SIOP07).pdf(Accessed: 9 October 2016).

[55] The Turkish Language Association.(2010). Genelsözlük: Tatmin [General dictionary:Satisfaction. (online), Available: http://www.tdk.gov.tr/TR/GenelSozBul.aspx?F6E10F8892433CFFAAF6AA849816B2EF437 6734B (Accessed 11, March, 2017).

[56] Woods, A. M.(2002). Maintaining Job Satisfaction; Engaging Professionals as Active Participants. The Clearing House. 75, No. 4, $186-189$.

[57] Wood, S. (2008). Job Characteristics, Employee Voice and Wellbeing in Britain. Industrial Relations Journal, 39, No. 2, 153-168.

[58] Zembylas, M. and Papanastasiou,E.C.(2006). Sources of Teacher Job Satisfaction and Dissatisfaction in Cyprus. A Journal of Comparative Education, 36(2), (online). Available:www.sciepub.com/reference/ 134044. Accessed on, 30, March, 2017.

[59] Zemmelman,S. Harvey .D. (1993). Best Practice: New Standards for Teaching and Learning in America's Schools. Portsmouth, NH: Heineman.

Citation: AndrewKasaija, et.al. "Analysis of the Ugandan Experience on Teacher Job Satisfaction and Students' Academic Performance at Uganda Certificate of Education in Secondary Schools in Western Uganda" International Journal of Research in Sociology and Anthropology (IJRSA), vol 6, no. 1, 2020, pp. 0918. doi: http://dx.doi.org/10.20431/2454-8677.0601002.

Copyright: (C) 2020 Authors. This is an open-access article distributed under the terms of the Creative Commons Attribution License, which permits unrestricted use, distribution, and reproduction in any medium, provided the original author and source are credited. 